\title{
Is investing in apprentices related to decision-makers' altruism and their high time preference?
}

Citation for published version (APA):

Jansen, A. (2016). Is investing in apprentices related to decision-makers' altruism and their high time preference? ROA. ROA Research Memoranda No. 002 https://doi.org/10.26481/umaror.2016002

Document status and date:

Published: 01/01/2016

DOI:

10.26481/umaror.2016002

Document Version:

Publisher's PDF, also known as Version of record

\section{Please check the document version of this publication:}

- A submitted manuscript is the version of the article upon submission and before peer-review. There can be important differences between the submitted version and the official published version of record.

People interested in the research are advised to contact the author for the final version of the publication, or visit the DOI to the publisher's website.

- The final author version and the galley proof are versions of the publication after peer review.

- The final published version features the final layout of the paper including the volume, issue and page numbers.

Link to publication

\footnotetext{
General rights rights.

- You may freely distribute the URL identifying the publication in the public portal. please follow below link for the End User Agreement:

www.umlib.nl/taverne-license

Take down policy

If you believe that this document breaches copyright please contact us at:

repository@maastrichtuniversity.nl

providing details and we will investigate your claim.
}

Copyright and moral rights for the publications made accessible in the public portal are retained by the authors and/or other copyright owners and it is a condition of accessing publications that users recognise and abide by the legal requirements associated with these

- Users may download and print one copy of any publication from the public portal for the purpose of private study or research.

- You may not further distribute the material or use it for any profit-making activity or commercial gain

If the publication is distributed under the terms of Article $25 \mathrm{fa}$ of the Dutch Copyright Act, indicated by the "Taverne" license above, 
Is investing in apprentices related to decisionmakers' altruism and their high time preference?

Anika Jansen

\section{ROA Research Memorandum}

ROA-RM-2016/2

Researchcentrum voor Onderwijs en Arbeidsmarkt | ROA Research Centre for Education and the Labour Market | ROA 


\title{
Is investing in apprentices related to decision- makers' altruism and their high time preference?
}

\author{
Anika Jansen \\ ROA-RM-2016/2 \\ February 2016
}

Research Centre for Education and the Labour Market Maastricht University

P.O. Box 616, 6200 MD Maastricht, The Netherlands

$\mathrm{T}+31433883647 \mathrm{~F}+31433884914$

secretary-roa-sbe@maastrichtuniversity.nl

www.roa.nl

\footnotetext{
* The ROA Research Memorandum Series was created in order to make research results available for discussion, before those results are submitted for publication in journals.
} 


\section{Abstract}

\section{Is investing in apprentices related to decision-makers' altruism and their high time preference?**}

In this article, the relation between firms' engagement in apprenticeship training and two important economic preferences, i.e. the decision maker's altruism and time preference, is analyzed. Firstly, the relation between these two preferences and a firm's decision to provide apprenticeship places (extensive margin) is examined. Secondly, for firms that train, the effect on the amount of investments in apprenticeship training (intensive margin) is analyzed. The results show that the degree of altruism of a decision maker is positively, albeit weakly significant, associated to the probability to provide apprenticeship places as well as substantially related to the amount of investments in apprenticeship training. Time preferences are not related to the training decision (extensive margin) but significantly related to the amount of investments in training.

JEL classification: J24, M53, D92, D64

Keywords: training decision, apprenticeship, altruism, time preference

Anika Jansen

Federal Institute for Vocational Education

and Training

Robert Schuman Platz 3

53175 Bonn

Germany

jansen@bibb.de

** I thank Andries de Grip and Ben Kriechel, Didier Fouarge, and Raymond Montizaan for comments and valuable suggestions. 


\section{Introduction}

The dual training system in Germany has an important role in facilitating the introduction of young people to the labor market and in safeguarding the availability of skilled workers. In overall terms, $53.5 \%$ of the workforce has been trained within the dual system (Statistisches Bundesamt 2014) and $87.5 \%$ of all firms employ such workers ${ }^{1}$. Nonetheless, the rate of training firms has declined in recent years. In 2014 , only about $20 \%$ of all firms in Germany decided to offer apprenticeship training. For the functioning of the dual vocational system, a participation of sufficient firms by providing apprenticeship places is pivotal. In order to increase or at least stabilize the number of firms providing training, the driving forces behind the training decisions have to be understood. For this reason, various attempts have been made to explain the firm's decision to provide apprenticeship places.

Firms decide to provide training when the expected benefits exceed the expected costs (e.g. Acemoglu \& Pischke, 1998; Becker, 1962). Benefits can either accrue in the short term during the training period itself in the form of productive contribution of apprentices or in the long term upon retention of the apprentices in the form of a wedge between the retained apprentices' productivity and their wages. Accordingly, two main economic motives prevail $^{2}$. Some firms train because of the so-called production motive (see Lindley (1975) for a first discussion of this motive), which means that they use their apprentices as a cheap substitute for unskilled and semi-skilled labor. Those firms usually do not retain their apprentices and already benefit from training in the short run, i.e. they do not have to incur any costs for training apprentices. Mohrenweiser \& Backes-Gellner (2010) find that about $19 \%$ of all firms in Germany are production oriented. Other firms train because of the investment motive. Those firms mostly retain their apprentices and can recoup the costs that they have incurred at a later stage (see Merrilees, 1983). Therefore, those firms are willing to make substantial initial investments.

A further explanation for firms' training engagement is that firms train because of social responsibility. Some firms might not only be profit maximizing but instead also benefit from an increased utility of third parties. This motive has often been mentioned (Beicht, Walden, and Herget 2004; Schönfeld et al. 2010), but never explicitly analyzed. Another

1. This share includes firms that employ at least one worker with either an apprenticeship certificate or a master craftsman certificate as the highest qualification (Data source: BIBB Establishment Panel on Training and Competence Development 2013; own calculations).

2. Other motives that were analyzed were the screening motive (Franz \& Zimmermann, 2002; Stevens, 1994) and the reputation motive (Sadowski, 1980). A good overview of the training literature is provided in Wolter \& Ryan (2011). 
explanation for the differential in firms' training engagement might be related to the different importance they put on the long-term benefits.

In this paper, I analyze whether firms' training decisions may be influenced by the economic preferences of the decision makers within the firm. As with any other firm decision, the decision whether or not to train apprentices is eventually taken by an individual, i.e. the firm owner or manager. While in recent economic literature the influence of individual economic preferences on employees' and consumers' decisions has become broadly accepted, the literature on the influence of individual preferences on management decisions is rather scarce (e.g. Armstrong \& Huck, 2010; Certo, Connelly, \& Tihanyi, 2008). Also in the training literature, the influence of individual preferences on the firms' training strategy has not been analyzed. However, with respect to firms' training decisions, the influence of especially two important individual preferences is likely:

Firstly, training apprentices involves a clear time dimension. Cost and benefit surveys of the provision of apprenticeships have shown that training apprentices is costly for most firms (Schönfeld, Wenzelmann, Dionisius, Pfeifer, \& Walden, 2010). In the long-term, however, when firms retain apprentices after the completion of the training period, the investments pay off due to numerous advantages of internally trained workers in contrast to externally trained workers. A low preference for the present of the decision makers should hence be a prerequisite for making these long-term investments. In contrast, if decision makers highly reward current benefits, they are likely to refrain from taking on apprentices and are instead more likely to search for workers on the external labor market who have already been trained. Moreover, decision makers who have a high time preference might tend to ignore their future need for skilled workers. The decision maker's time preferences could thus play an important role in taking decisions on training investments.

Secondly, providing training positions is not only beneficial for the firm itself but also creates huge monetary and non-monetary benefits for the apprentices and society as such. If decision makers in firms also take into account the expected impact on apprentices and society, the cost benefit relation could alter, and they might decide to train even if training is not beneficial for the firm in purely monetary terms. Therefore, another important economic preference that could influence firms' training decisions is altruism.

The two preferences are also chosen because of their relevance in the political discussions on the approaches to incentivize firms to train, in which it is implicitly assumed that firms training behavior is also influenced by social and time preferences. Firms are especially by unions - often accused of shortsightedness in their training strategy (Ulrich 2004). Hence, prominent approaches to convince firms to train apprentices are directed 
towards raising the awareness for the future need of skilled labor ${ }^{3}$. However, it is not clear whether these approaches are really targeted in the right direction. This would only be the case if it was really short-sightedness rather than cost-benefit considerations that prevent firms from engaging in training. Analyzing the influence of time preferences on the firms training investment provides us with initial evidence of whether this condition is fulfilled. Moreover, in the political discussion and throughout this strand of literature, it is often mentioned that firms have a social responsibility to train apprentices (Busemeyer 2009). For that reason, campaigns to convince firms to train emphasize the social benefits for young school graduates and for the economy as a whole ${ }^{4}$. However, the actual influence of social preferences on firms' training policies has never been explicitly analyzed. Do firms really take into account the utility they create for others in their training decision? If this were the case, altruistic decision makers should be more willing to invest in training. This paper fills these research gaps by analyzing these two important economic preferences and their relation to the investments in apprentices.

The analyses are based on the German BIBB Cost Benefit Survey 2012/13, which includes firm information, such as the training decisions and the training costs, as well as information on the economic preferences of the individuals who are responsible for the firm's decision to provide apprenticeships.

The contribution of the paper to the literature is twofold. Firstly, the paper adds to the literature on the determinants of training investments and training decisions by introducing a further explanation for the variation in training costs and training engagement. Secondly, the paper adds to the behavioral economics literature on social and time preferences, which has mainly focused on individuals in their role of consumers or workers. In contrast, literature on the effect of economic preferences on managerial decisions is scarce and tends to exist in the field of market interactions, with regard to collusive, vengeful, and imitative behavior (Armstrong and Huck 2010). This paper complements this literature by analyzing the effects of two relevant economic preferences on two important management decisions, i.e. the decision to train and the amount of investments in apprentice training.

3. The training pact $(2010$ - 2014) signed by the Federal Government and the central associations of the private sector aims to provide more in-company training. One measure that originates from this pact was to set up an information campaign that aimed to increase the awareness for the future skilled workers (http://www.praktisch-unschlagbar.de/content/ueber-die-iobb-179.php). One further measure arising from the new training pact signed in December 2014 is the "Week of apprenticeships", also aiming to increase firms (and students) awareness of the future training benefits (http://www.arbeitsagentur.de/web/content/DE/Veroeffentlichungen/Weisungen/Unternehmen/Detail/i ndex.htm?dfContentld=L6019022DSTBAI712091).

4. See for example the Alliance for Initial and Further Training, which was established in 2014. 
The paper is organized as follows. The next section presents the theory and derives the respective hypotheses. The third section introduces the database and the operationalization of the main independent variables, and section four presents the empirical strategy. Section five presents the regression results and some robustness checks. Section six concludes.

\section{Theory and hypotheses}

\subsection{Theoretical framework: costs and benefit of training}

According to economic theories of investment in human capital, the expected costs and benefits of training determine whether a firm provides training to its employees or not. Two forms of benefits are possible - short and long-term benefits. Short-term benefits can accrue because apprentices contribute productively to the economic output of the firm. In about $30 \%$ of all German firms providing training, these short-term benefits are so high that training pays off during the training period itself (see Figure $A 3$ in the Appendix). The remaining firms rely on the long-term benefits. The long-term benefits essentially accrue due to the gap between workers' productivity and their wages (Acemoglu and Pischke 1998; Becker 1962). This is for example due to the provision of firm specific skills which make internally trained workers more productive in the long term. Moreover, theory predicts that, due to a certain degree of market power, firms are able to pay their internally trained workers a wage below their productivity (Bhaskar, Manning, \& To, 2002 and for reviews see Leuven, 2005; Wolter \& Ryan, 2011). Moreover, by providing apprenticeships firms become more independent from the external labor market and can circumvent production losses and save high recruitment costs (Stevens 1994). For Germany, Walden (2007) and Mühlemann et al. (2010) find that the probability to train depends substantially on those long-term benefits. Differences in short term training costs nearly do not have any influence on the training decision. ${ }^{5}$

Economic preferences fit into this costs benefit framework in the following way. Firstly, time preferences determine the strength to which the long-term benefits influence the current training decision. Secondly, via altruism the increased benefits of apprentices and society can enter the firms' utility function. As economic preferences refer to an individual, the cost benefit framework is extended so that it is not the firm as an abstract entity which

5. This is not everywhere the case. In Switzerland for example, short term training costs have a strong influence on the training decision. Comparing the actual and the hypothetical training costs of nontraining firms in Switzerland, Mühlemann et al. (2005) and Wolter, Mühlemann, and Schweri (2006) have shown that cost-benefit considerations have a significant influence on the decision to train apprentices. 
makes the training decision, but instead a person who is in charge of the training decision within the firm.

The influence of economic preferences on individual behavior is extensively documented in various studies in the field of behavioral economics (e.g. Camerer, Loewenstein, \& Rabin, 2004; Fehr \& Schmidt, 2006). Also in the field of educational choices, the literature has shown that economic preferences have an important effect. Fouarge, Schils, \& Grip (2013) have shown that the workers' willingness to participate in continuous training also depends on their future orientation. Regarding firm behavior, less evidence on the influence of economic preferences exists. Nonetheless, some studies indicate that also managers acting on behalf of their firms can make decisions that depart from rational behavior and the profit maximizing paradigm (Armstrong and Huck 2010; Certo, Connelly, and Tihanyi 2008). In the following, I will present two main economic preferences and why especially time preferences and altruism are expected to influence the training decision and training investment.

\subsection{Time preferences - training apprentices as an intertemporal investment decision}

Several studies have found that training apprentices in Germany is not self-supporting in the short run (see e.g. Schönfeld et al., 2010). On average, firms have to invest in training apprentices during the contract duration of an apprenticeship. For more than $70 \%$ of all firms, training apprentices is an investment which pays off only in the future by retaining the apprentices upon their qualification. Even for the remaining $30 \%$ of firms, for which training pays off in the course of the training program, i.e. in the second or third year ${ }^{6}$, an initial investment upon the start of the program is necessary. Thus, training apprentices always requires an upfront investment, which pays off at a later stage.

In order to assess whether the investment is worthwhile, the future training benefits have to be estimated and discounted to obtain their present value (see chapter 7.2 in Borjas, 2008). ${ }^{7}$ In a firm potentially interested in providing training, this is the task of the manager or the owner. A decision maker in a potential training firm only decides to train if the present

6. Data from the BIBB Cost Benefit Survey 2012/13 show that apprentices' productive contributions increase during the training program. At the beginning apprentices are less productive and receive more training. At the end of the training period, they are more competent and can be better allocated to productive tasks. As a result, the training costs decrease during the training period.

7. The influences of individual time preferences that depart from the interest rate are (only) recognized in the human capital literature when it comes to workers individual training or educational decision (see chapter 7.4 on human capital in Borjas, 2008). 
value of the long-term benefits is at least as high as the immediate training investments. ${ }^{8}$ The condition is formulated in the following equation.

(1) Inv $_{i} \leq \frac{1}{1+\delta_{i}} \cdot$ Long - term benefits f $_{i}$

The training investments are indicated by $\operatorname{Inv}_{i}$ and $\delta$ denotes the individual time preference. Equivalent to the discount rate, a high value of $\delta$ indicates a high preference towards the present and vice versa. ${ }^{9}$ Accordingly, the present value of the long-term benefits is obtained by multiplying the long-term benefits by $\frac{1}{1+\delta_{i}}$. When preference towards the present is high, the present value of the long-term benefits is low and vice versa. Assuming constant training costs and constant long-term benefits, a low value of future benefits renders the training decision less attractive. Therefore, the higher the preference for the present of the decision maker, the lower the probability to provide apprenticeship places will be, as long as everything else is equal. This leads to the following hypothesis.

H1: A higher preference towards the present is negatively related to the probability to offer apprenticeship places.

Equation 1 also illustrates that firms would train in the presence of high training costs if the preference towards the present is low. In contrast, firms are less willing to make investments in training, when, due to a high preference towards the present the present value of future benefits is low. Thus, assuming constant long-term benefits, firms with high preference towards the present should be willing to accept lower training investments and vice versa.

Moreover, in case the decision maker can influence the training organization, the effect of time preferences could be channeled via an additional mechanism. To some degree the decision makers can influence the training cost by determining the trainer hours and the time the apprentices are allocated to productive tasks. A higher quality apprenticeship with many teaching and learning hours is probably associated with higher training costs. At the same time, a high quality apprenticeship will probably increase the productivity of the apprentice at the end of or after the training program. Accordingly, especially if firms want to retain their apprentices, they should have a long-term interest in training them well. $A$

8. Accordingly, it can be expected that for all training firms in the data set, the present value of the future benefits are at least as high as the training investments.

9. Most research analyzing intertemporal trade-off decisions attempt to determine a specific discount function, which describes the changes of the discount factor depending on the size of the reward and on the time when the reward will be handed over (see e.g. Benhabib, Bisin, and Schotter 2010). The scope of this paper is much simpler in the way that it just looks at the intertemporal trade off irrespective of the size and the timing of the reward. 
shortsighted decision maker might focus only on the short term training costs and might organize the training accordingly. Thus, there are two reasons for a relation between time preferences and the training investments. The first reason refers to the presumption that decision makers with low preferences for the present accept higher exogenous training costs. The second reason refers to the presumption that trainers actively organize training in a different way depending on their time preferences. The resulting hypothesis is the following.

H2: A higher preference towards the present is associated to lower investments in apprenticeships.

It is likely that this relation is especially pronounced for firms with high training investments, as firms that have low costs or even do not have to incur any costs for training would benefit from training anyway and do not have to rely or rely to a lower extent on potential future benefits. Thus, the discount factor with which future benefits have to be weighted should play a minor role for firms with low training costs.

\subsection{Altruism - training apprentices as a social action}

For young school leavers in Germany who do not aim for a university career, starting an apprenticeship program is the main track to receive a formal vocational qualification at the intermediate level. ${ }^{10}$ In 2013, 54.5\% of the relevant age cohort started an apprenticeship (Uhly 2015). For these youngsters, apprenticeship programs give access to the labor market and ensure their integration in society. Therefore, firms' participation in the dual system of apprenticeship training is pivotal for the integration of young people in the labor market. In Germany, youth unemployment rates are relatively low, which is often attributed to the dual system. Thus, training does not only yield benefits for the firm but is also socially beneficial. Smits \& Zwick (2004) present evidence that German firms providing training are indeed very conscious of the positive impact of training on society and are aware of their social responsibility.

However, even though the recent development shows that fewer school graduates opt for an apprenticeship, the number of firms that is willing to provide training places is still not high enough for all school leavers that apply for an apprenticeship place (Matthes et al. 2015). The excess demand of apprenticeship places even enhances the importance of firms' engagement in the dual training system. Appeals towards their social responsibility should convince firms to provide training places. Busemeyer (2009) maintains that those appeals

10. Only very few occupations are taught in a vocational school setting. 
can be successful. He argues that especially in the 1980s, firms increased the supply of training places and trained in excess of their needs because they responded to appeals of the chambers of industry and commerce and employer associations. The author concludes that firms often are not aware of the exact costs of apprenticeship training, which leaves leeway for social considerations and the acceptance of social responsibility. In this context, Maier and Walden (2014) found that before the nineties firms' supply of apprenticeship places reacted to students' demand for apprenticeship places, which they interpret as a sign that appeals to community spirit were effective in this time period. ${ }^{11}$ Indeed, according to the BIBB Cost Benefit Surveys, many training companies state that social responsibility is an important reason to participate in the training system (Beicht, Walden, and Herget 2004; Schönfeld et al. 2010). Also a recent qualitative study by the BIBB showed that training firms tend to name social responsibility as a reason to train apprentices much more often than non-training firms (Foraus 2015).

If social responsibility is a reason to train apprentices, the mechanism must work via the person or a group of persons within the firm who is in charge of this decision. This can be the firm owner, manager or a group of managers. In order that the manager opts for training because of social responsibility, two prerequisites must be fulfilled. Firstly, the individual in charge of this decision must be aware of the positive social impact of the training decision. Secondly, the individual must care enough about the benefits of other people in order to act accordingly. That means decision makers must be to some degree altruistic ${ }^{12}$. Altruism means that the act of giving enhances the givers' utility even though they do not receive anything in return (Andreoni 1989; Becker 1974), either because the actor enjoys giving or because he cares about the recipient. Fehr \& Schmidt (2006) define altruism as "[...] a form of unconditional kindness", an act which is not "[...] a response to a favor received".

In the field of private individual decisions, the impact of social preferences on behavior is extensively analyzed. It is widely accepted that not only material self-interest motivates decision makers, but also the well-being of others. Carpenter \& Myers (2007), for instance, found that more altruistic people are more likely to volunteer. However, in the field of management decision, especially with regard to the training decision, empirical evidence on the influence of altruism is scarce.

11. However, they also find that after the nineties the strength of this relation has decreased. They deduce that therefore also the effectiveness of appeals to the community spirit has declined.

12. Apart from altruism, other forms of social preferences like fairness and reciprocity exist (Fehr \& Schmidt, 2006). In general, social preferences describe the idea that individuals do not only care about their own pay off but also care about others' payoff. However, in the context of the firms' training decision, where firms usually do not know the apprentice before the start of the training program, it is reasonable to expect that altruism is the most relevant form of social preferences. 
An altruistic decision-maker takes the external utility he produces into account in his training decision. This means that the decision maker's utility will be enhanced by providing apprenticeship places from which youngsters can benefit. Then, the utility obtained by enhancing others' well-being can partly compensate for the training costs. Therefore, a higher degree of altruism is ceteris paribus associated with a higher probability of providing apprenticeships places, which is formulated in the following hypothesis.

H3: The degree of altruism is positively related to the probability of providing apprenticeship places.

The relation between training investments and altruism can be illustrated by including the utility of other persons in the decision makers' utility function. With each training place, the firm is creating a constant external positive utility. When the decision maker is altruistic, he would only decide to train if the training costs are equal or smaller than the long-term benefits plus the external utility. The degree of altruism of each decision maker determines to what extent the external utility enters the decision maker's utility function and is given by the parameter $\alpha_{i}$, which is bound between 0 and 1 .

(2) Inv $_{i} \leq$ Long - term benefits ${ }_{i}+\alpha_{i} \cdot \overline{\text { External utllity }}$

If the altruism parameter $\alpha_{i}$ is equal to zero, the decision maker's utility from training is entirely determined by the long-term training benefits minus the training costs, which means that observed investments must be equal or lower than the long-term benefits. If the altruism parameter is larger than zero, decision makers can obtain a positive net utility from training apprentices, even if the long-term benefits are lower than the training investments. This argumentation implies the following hypothesis.

H4: The degree of altruism is positively related to the investment in apprenticeships.

\section{Data and operationalization}

The analysis in this paper is based on the most recent BIBB Cost Benefit Survey 2012/13 collected by the Federal Institute for Vocational Education and Training (BIBB). The survey measures the costs and benefits of apprenticeship training from the firms' perspective. The sample was drawn from the administrative firm register of the Federal Employment Agency, which contains all German firms that are subject to social security contribution. Therefore, the data are representative for all German firms with at least one employee. The data set include a total of 3,032 training and 913 non-training firms. In the data analysis based on all firms, sampling weights are used to account for the fact that training firms are overrepresented. 
The field work of the survey was conducted by infas (Institute for Applied Social Sciences) between September 2013 and April 2014. The interviews were designed as computer assisted personal interviews (CAPI). The interviewee was always the person responsible for training in the firm. In 1,477 cases, the owners of the firm were interviewed. The remaining interviewees were employees of the firm, mostly managers of human resources or training departments.

The dependent variables of the analyses are the firm's decisions to train apprentices and the firm's investments in apprenticeships. The training decision indicates whether a firm has been training an apprentice at a certain effective date (30.9.2012). The firm's training investments are given by the net costs of apprenticeship training. The net costs are the difference between the gross training costs and the productive contribution of the apprentices during their training. The gross costs consist of the wages of apprentices, the costs for training personnel, machines and infrastructure, and other costs. The net costs always refer to one apprentice and one training year. For a detailed description of the training costs see (Schönfeld et al. 2010).

The main independent variables of interest are the economic preferences of the decision maker in the firm. All other questions in the survey refer to the firm in general and not specifically to the person interviewed. As the questions on the economic preferences refer to the individual and not to the firm, they were only asked in interviews with one respondent, which was the case in most of the interviews. In only 276 out of all 3,945 interviews, more than one respondent took part in the interview. Moreover, the individual questions were only addressed to respondents who were involved in the decision whether and how many apprentices are trained. That can either mean that respondents make the training decisions alone or together with other colleagues. Only 256 interviewees were not involved in the training decision at all and were therefore excluded from the analysis.

To measure the degree of altruism of the respondents, we included a hypothetical choice question in the cost benefit survey. Throughout this survey, we did not have the possibility to conduct experiments, which are usually employed to measure altruism ${ }^{13}$. However, trying to be as close as possible to existing measures of altruism, in which decision makers have to allocate real resources, we employed a question that is based on the idea of the dictator game. In experimental economics, the dictator game is usually employed to

13. Murphy \& Ackermann (2012) provide a review of existing measurement methods for social preferences focusing on preferences for allocation of recourses. Questionnaires regarding verbally expressed altruistic attitudes are not considered in their review as they believe that the better approach to measure social preference is to have people making decisions with real consequences. This is probably correct, but in practice was not feasible as we had to rely on a measure we could readily include in an already existing survey. 
elicit altruism. In this game, the subject receives a fixed amount of money and can then decide to give some share of this amount to another participant of the game. The amount spent to the other subject is used as an indicator for altruism (see e.g. (Carpenter and Myers 2010). The exact wording of the question is taken from a module of suggested survey questions for key economic preferences, which also have been experimentally validated (see (Falk et al. 2013). The question asks the respondents how much of an amount of $€ 1,000$ they had just won they would donate to charity:

Q1: "Imagine you have won $€ 1,000$ in a prize competition. How much of this amount would you, in your current situation, donate to charity?"

The answer of the respondents denotes their altruistic inclination. The higher the value reported, the higher is their degree of altruism. Falk et al. (2013) have shown that the hypothetical donation correlates significantly with the respective experimental measure ${ }^{14}$ with a correlation coefficient of 0.298 . Another study uses an index of this measure combined with another altruism measure ${ }^{15}$ and found that this index also correlates strongly with real pro social behavior including donating, volunteering time, helping strangers, or sending money or goods to other people in need (Falk et al. 2015).

Also time preferences are usually measured in experiments instead of surveys ${ }^{16}$. When measured in surveys, the concept of time preferences has been captured by either asking questions on the degree of impatience or on future orientation. Vischer (2012) measures impatience by asking respondents about how impatient they are in general and shows that his measure of impatience correlates with actual behavior ${ }^{17}$. Fouarge et al. (2013) measure future orientation by using a scale containing 12 different items related to future orientation. In his meta survey of studies on non-standard preferences, DellaVigna (2009) conceptually equates time preferences with self-control problems. In this study, I use the answers to the following question as an indicator of the preference towards the present.

Q2: To which degree does the following statement apply to you? "I tend to postpone things even though it would be better to get them done right away."

14. The respective experimental measure was a dictator game in which subjects could spend a share of an endowment of 300 points to a charity organization (see Falk et al., 2013).

15. The index is calculated by weighing responses to two survey items (the donation decision used in this paper and a qualitative altruism question) using the weights obtained from an experimental validation procedure. The altruism question used in this paper has a weight of 0.54 .

16. Wang, Rieger, \& Hens, (2011) measure time preference by letting the respondents answer an intertemporal choice question.

17. See also Vischer et al. (2013) for a review of this question. 
The respondent can indicate his answer on a scale from 0 (does not apply at all) to 10 (applies completely). The higher the answer of the respondent, i.e. the higher the tendency to postpone things, the higher is his preference for the present.

In the Appendix, I show the distribution of the two main independent variables. Figure $\mathrm{A} 1$ and figure $\mathrm{A} 2$ show the distributions of altruism and time preferences, respectively. The figures show that even though both distributions are left skewed, the respondents used the whole range of response possibilities.

Table A2 shows the descriptive statistics of main variables of interest. The average investment in training, i.e. the net costs, per apprentice and per year in the analyzed data is $€ 5,657$ and range from $-31,000$ to 58,000 . Moreover, respondents state that they are willing to give on average $€ 185$ to charity. The standard deviation lies at 247 . To describe their tendency to postpone things, respondents indicate on a scale from 1 to 10 on average a 2.85 , with a standard deviation of 2.61 .

\section{Empirical strategy}

To test the derived hypotheses empirically, first a probit regression is conducted which relates decision makers' altruism and time preferences to whether the respective firm is a training firm or not. Equations 1 and 2 from the hypothesis section show that the willingness to incur costs for apprenticeship training is strongly related to the expected long-term benefits and thus illustrate the necessity to control for variables that indicate firms' possibility to make long-term benefits. ${ }^{18}$ The estimated regression is as follows.

$$
\operatorname{Train}(\text { yes } / \text { no })_{i}=\text { Altruism }_{i}+\text { Present }_{i}+\beta_{i} L T B_{i}+\varepsilon_{o t}
$$

Train (yes $/ n o)_{i}$ is a binary variable, which is one if the firm is a training firm and zero if the firm does not provide training. The variable Altruism $_{i}$ represents the degree of altruism of the decision maker within the firm i, and Present $t_{i}$ represents the degree of preference towards the present of the decision maker within firm $\mathrm{i}$. The long-term benefits are denoted by $L T B$ and are measured by a variety of variables.

Accordingly, the second regression is an OLS regression based only on those firms that train, which relates altruism and time preferences to the amount the firm invests in apprenticeship training $\operatorname{Inv} v_{i}$.

$$
\text { Inv }_{i}=\text { Altruism }_{i}+\text { Present }_{i}+\beta_{i} L T B_{i}+\varepsilon_{o t}
$$

18. The coefficient would be biased if the potential for long-term benefits was related to the characteristics of the decision makers. 
In the following, I present the variables that are intended to capture the long-term benefits for the OLS regression with the training investments as the dependent variable. The probit regression includes the same variables except those that specifically refer to firms providing training. In our data set, we can only observe the training investments as the longterm benefits are difficult to monetize. Therefore, I control for a number of variables that capture the variation in the firms' potential to accrue long-term benefits.

The long-term benefits depend substantially on the firms' outside options, i.e. the possibilities to recruit skilled workers on the external labor market. If it is relatively difficult for firms to find skilled workers in the relevant occupation on the external labor market, training their own apprentices becomes more beneficial and firms are more willing to invest in apprenticeship training. The possibilities to recruit new workers depend on the external labor market conditions. This variation is captured by a number of variables. Firstly, I add a variable that subjectively assesses the availability of skilled workers on the external labor market. Other control variables that indicate the variation in labor market conditions are economic sector, firm size, and region (German Bundesländer). The potential for long-term benefits are also expected to vary substantially between different occupations. Therefore, I further control for occupations. Moreover, the conditions on the product market could also have an effect on the firms' incentives to train. ${ }^{19}$ Therefore, I add a variable on whether the firm is subject to high pressure of competition. I also control for the retention strategy of the firm, which indicates whether a firm is rather production or investment oriented. Usually, investment-oriented firms expect much higher post training benefits than productionoriented firms and are therefore also willing to incur higher training costs. Further control variables for long-term benefits are the actual retention rate, share of apprentices that are still in the training firm after three years, and the existence of a works council.

As the answers of the respondents might depend on their income due to the decreasing marginal utility of income, I control for the respondents' income possibility. As we do not have information on the individual income of the respondent in our data set, I use the average wage of a manager within the firm as a proxy for the respondent's income. I further control for the number of apprentices as this variable is usually a strong determinant of average training costs due to the existence of economies of scale.

19. The theoretical hypotheses on the direction of this effect are mixed. Gersbach, H., Schmutzler (2006) argue that if product differentiation is low and competition is high, firms train less because workers can easily switch to another firm and the firms' market power decreases. Bassanini \& Brunello (2007) acknowledge this effect, but also argue that more training reduces the unit costs and like this the price, which in turn has a positive effect on the demand. The effect of the price on the demand is stronger in competitive product market. Then more competition on the product market could also lead to more firm sponsored training. 
In principle the control variables should be the same for the probit regression. However, in the probit regression I have to exclude those variables that are only relevant for training firms, such as training occupation, retention strategy, actual retention rate, share of apprentices that are still in the training firm after three years, and number of apprentices.

\section{Results}

In the following, some descriptive results on the relation between altruism (preference towards the present) and the training decision and investments are firstly presented. Subsequently, I present the regression results with the variables previously described. I first discuss the results from the probit regression, referring to the probability to train (extensive margin), and then turn to the OLS regression, referring to the amount of investments in apprenticeship training (intensive margin).

\subsection{Descriptive results}

The red line in Figure 1 shows the descriptive relation between the degree of altruism of the decision makers and the training participation rate, i.e. the number of firms providing apprenticeship places in relation to all firms. In specific terms, it shows the average training participation rate for different quartiles of the altruism distribution. The figure illustrates that the relation between the degree of altruism and the training probability is small but continuous because with each quartile of altruism, the training participation increases. The lowest quartile lies at zero, meaning that $25 \%$ of all respondents stated they would not donate any money of the $€ 1,000$ they had just won to charity. In this group the training participation rate lies at $19 \%$. The next quartile includes decision makers who would donate more than 0 but not more than $€ 100$ to charity. In this group, $21 \%$ of the firms provide apprenticeship places. In the third quartile, $23 \%$ of all companies decide to train. In the highest quartile, which comprises decision makers who would donate more than $€ 300$, the training participation rate is $25 \%$.

Figure 1 also shows the average investment in apprenticeship training for the different quartiles of the altruism distribution. Again, the training investments increase with each quartile steadily. While firms with decision makers in the lowest quartile of the altruism distribution spend about $€ 5,000$ per year on their apprentices, firms with the most altruistic decision makers spend more than $€ 6,000$ on training an apprentice. Although the relationship is not very strong, it is steadily increasing. 
Figure 1: Investments in apprenticeship training and training probability - differentiated by degree of altruism

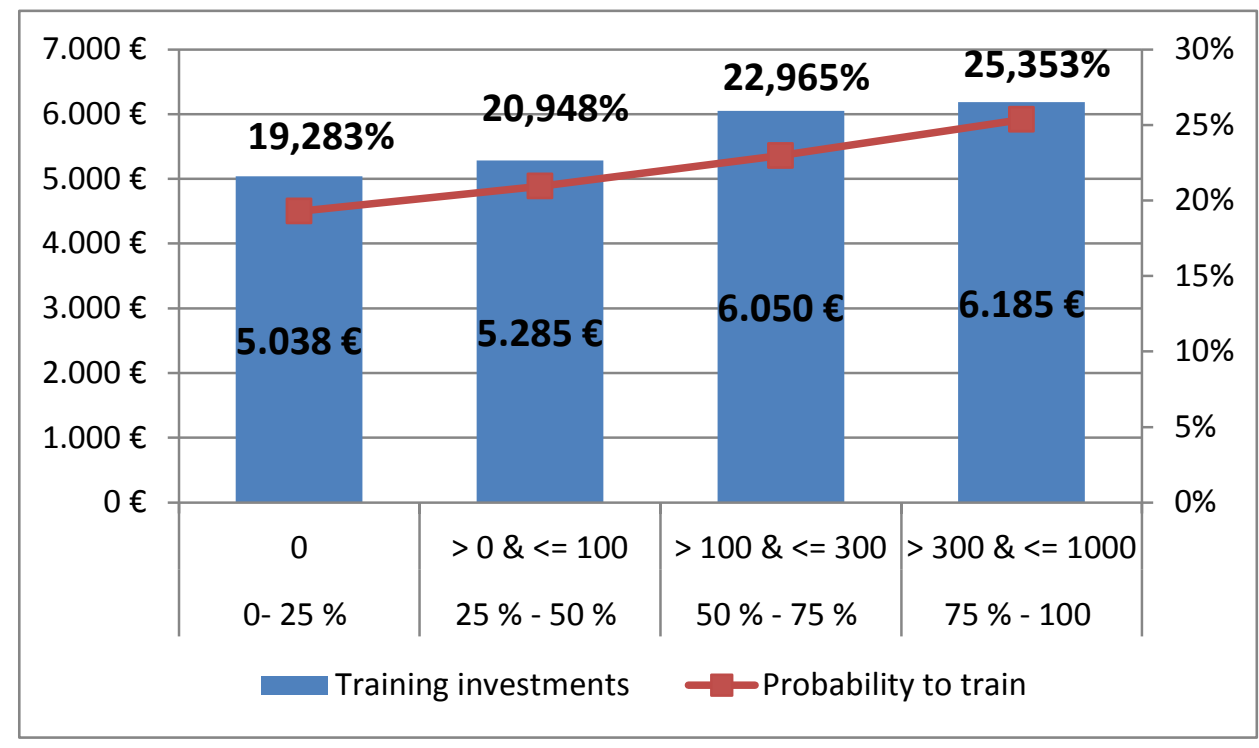

Figure 2 shows the relationship between the preference towards the present and the training participation rate. In contrast to the altruism variable, this relation is not very pronounced. The lowest quartile comprises those decision makers whose response to the question whether they tend to postpone things was that this statement does not apply to them at all. In this quartile, the training participation rate lies at $20 \%$. In the second quartile are those persons that marked either a 1 or a 2 on the scale from 0 to 10 . Here, the training participation lies at $25 \%$. Interviewees who indicated a value between three and five belong to the third quartile and those who marked a value above 5 to the fourth quartile. In those quartiles, the training participation decreases again and lies at $22 \%$ (third) and $21 \%$ (forth), respectively. The relation between the preference towards the present and the actual amount of training investments is more pronounced. From the first to the third quartile, the training investments decrease constantly, from about $€ 6,700$ to $€ 4,700$. Only in the highest quartile are training investments relatively high again with a value of nearly $€ 5,800$. 
Figure 2: Investments in apprenticeship training and training probability - differentiated by degree of preference towards the present

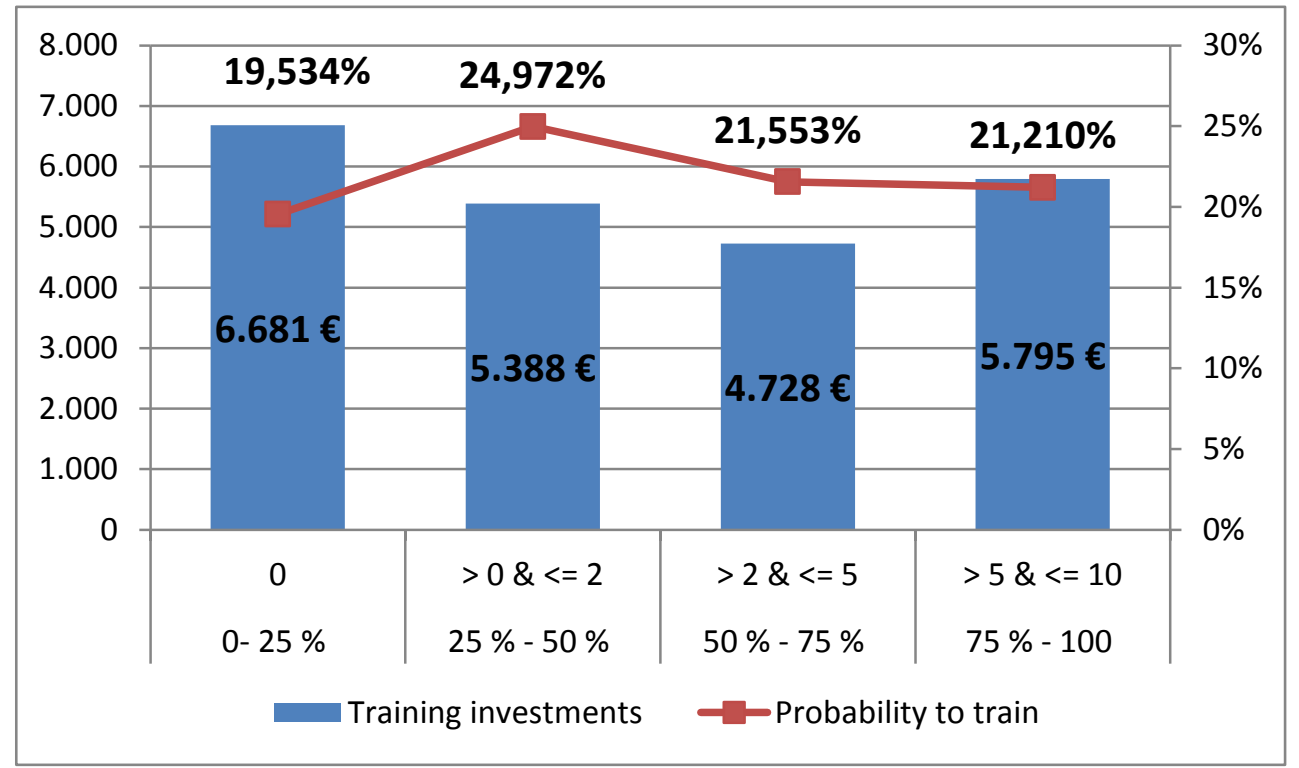

\subsection{Regression results}

Table 1 presents the relation between economic preferences and the likelihood of providing training places. The table shows the results of a probit regression ${ }^{20}$ displaying the beta coefficients (BC) and the marginal effects (ME). All independent variables that are displayed in Table 1 are standardized so that they have a standard deviation of one and a mean of zero. This allows a better comparison between the different independent variables. In addition to the variables shown in the table, controls for economic branch (19), firm size (4) and region (16 Bundesländer) are included.

Table 1 shows that the coefficient of altruism is significantly (10\% level) related to the probability of offering apprenticeship places. An increase of one standard deviation of altruism on average increases the likelihood to provide training places by 2 percentage points. Time preferences, on the other hand, are not significantly related to the firm's training decision. The coefficient is very small and not significant.

The coefficient of works councils is significant at the $5 \%$ level. Having a works council in the firm increases the probability to train by 3.6 percentage points. The availability of skilled

20. The same model was run using a logit regression. The results remain very similar. 
workers on the labor market is significant on the $10 \%$ level. The better the availability of skilled labor on the external labor market, the less likely is a firm to train. The effect size is comparable to the size of the altruism coefficient. The variable indicating the degree of product market competition and the respondents' wage are not significant.

Table 1: Dependent variable: training decision (yes/no); Probit regressions

\begin{tabular}{lcc}
\hline & $(3)$ & $(4)$ \\
& Probit: BC & Probit: ME \\
\hline & $0.0741^{*}$ & $0.0205^{*}$ \\
Altruism & $(0.04)$ & $(0.01)$ \\
& 0.0264 & 0.0073 \\
Preference for the present & $(0.05)$ & $(0.01)$ \\
& -0.0840 & -0.0232 \\
Respondents' wage & $(0.06)$ & $(0.02)$ \\
& $-0.0807^{*}$ & $-0.0223^{*}$ \\
Availability of workers & $(0.05)$ & $(0.01)^{* *}$ \\
& $0.1349^{* *}$ & $0.0373^{* *}$ \\
Works council & $(0.06)$ & $(0.02)$ \\
& -0.0658 & -0.0182 \\
Product market competition & $(0.05)$ & $(0.01)$ \\
& -0.4457 & \\
Constant & $(0.37)$ & \\
& -1388 & \\
\hline Log likelihood & 0.13 & 2983 \\
Pseudo R & 2983 & \\
Observations & &
\end{tabular}

Note: All independent variables are standardized, standard deviation in parenthesis, *** $\mathrm{p}<0.01, * * \mathrm{p}<0.05$, * p <0.1; Source: BIBB CBS 2012/13. Controls for economic branch (19), firm size (4) and Bundesländer (16) are included. $\mathrm{BC}=$ Beta coefficient and $\mathrm{ME}=$ Marginal effects.

Table 2 shows the relation between the economic preferences and the training investments based on all firms that train apprentices. The coefficients that are presented in the table are standardized beta coefficients. Apart from the variables displayed in the table, the models include controls for economic branch (19), firm size (4), Bundes/änder (16), and occupation (211). In all models, the training investments, measured by the net costs, are the dependent variable. The table shows how the coefficient for altruism and preference for the present change when different set of control variables are included.

Table 2 shows that the coefficient for altruism remains remarkably robust for all kinds of models, even though it slightly decreases with the introduction of additional control variables. While in the first model with only few control variables it lies at 0.06 , the coefficient in the last model, which includes the complete set of control variables, lies at 0.05. Through all combinations, the coefficient is significant. The number of observations 
varies between the models as not all firms have answered all the questions. The most conservative estimation as displayed in column 5 suggests that an increase of one standard deviation in altruism is related to an increase of 0.05 standard deviations of training investments.

In contrast to the altruism coefficient, the coefficient for preference towards the present even becomes stronger after the introduction of additional control variables. The coefficient obtained from the estimation of column 5 shows that an increase of one standard deviation of preferences towards the present is related to a decrease of 0.085 standard deviations of training investments.

The other variables also yield interesting results. The number of apprentices is always negatively related to the training investments, which is due to the existence of economies of scale in the training engagement. Moreover, the respondent's wage is significantly positively related to the training investment. Furthermore, firms with a works council spend significantly more on training than firms without a work council. The effect size is about 0.1 standard deviations. This is not surprising as Kriechel, Mühlemann, Pfeifer, \& Schütte (2014) also have found a significant effect of works councils on training investments with a similar data set.

Most variables indicating potential long-term benefits are also related to the training costs. The retention strategy seems to be important for the willingness to invest in training. Those firms that only sometimes retain their apprentices have significantly lower training costs compared to those who always retain their apprentices. Nonetheless, as soon as the control variables for retention rate and tenure are added, this effect becomes insignificant. In this vein, the variables retention rate and tenure of graduated apprentices are significant at the five \% level in explaining the training investments. Only the availability of skilled workers on the labor market is not related to the training investments.

The results show that on average firms that can expect more long-term benefits are indeed more willing to incur net costs. However, also after controlling for those long-term benefits, the coefficients for altruism and preferences towards the present remain significant in explaining the firms' willingness to invest in training. That shows that the economic preference of the decision makers has an additional effect on the training investments.

In an additional analysis, I check whether the effect of altruism on training investment could have a positive side effect on training quality. One variable which could be seen as an input-based measure for training quality is the amount of trainer hours that are allocated to each apprentice in an average week. Column 2 in Table A3 in the appendix shows the same regression as in Table 2, albeit with the total trainer hours as the independent variable. The coefficient for altruism is highly significant and twice as high as in the investment regression. Moreover, column 3 shows that as soon as the trainer hours are included as a control 
variable in the investment regression, the altruism coefficient becomes insignificant. This shows that the effect of altruism on the net training costs is mainly channeled by the trainer hours. As trainer hours can be seen as an input-based measure for training quality, this analysis shows that more altruistic decision makers are not only willing to invest more in training but are also more likely to provide a higher training quality. This is line with evidence from Smits (2006) who analyses the relation between the quality of apprenticeship training and the training motives. She finds that when firms are more investment oriented they provide higher quality apprenticeships. This effect can be only observed for the altruism variable. The preferences towards the present do not seem to be related to the trainer hours. 
Table 2: Annual investments in apprenticeship training per apprentice in Euro

\begin{tabular}{|c|c|c|c|c|c|}
\hline & $\begin{array}{c}(1) \\
\text { Net costs }\end{array}$ & $\begin{array}{c}(2) \\
\text { Net costs }\end{array}$ & $\begin{array}{c}(3) \\
\text { Net costs }\end{array}$ & $\begin{array}{c}(4) \\
\text { Net costs }\end{array}$ & $\begin{array}{c}(5) \\
\text { Net costs }\end{array}$ \\
\hline Altruism & $\begin{array}{c}0.060^{* * * *} \\
(0.66)\end{array}$ & $\begin{array}{c}0.057^{* * * *} \\
(0.65)\end{array}$ & $\begin{array}{c}0.053^{* * * *} \\
(0.65)\end{array}$ & $\begin{array}{c}0.055^{* * * *} \\
(0.68)\end{array}$ & $\begin{array}{c}0.050^{* * *} \\
(0.75)\end{array}$ \\
\hline Preference towards the present & $\begin{array}{l}-0.044^{* *} \\
(72.32)\end{array}$ & $\begin{array}{l}-0.048^{* * *} \\
(71.84)\end{array}$ & $\begin{array}{c}-0.046^{* *} \\
(71.54)\end{array}$ & $\begin{array}{l}-0.041^{*} \\
(74.15)\end{array}$ & $\begin{array}{c}-0.085^{* * * *} \\
(85.55)\end{array}$ \\
\hline Number of apprentices & $\begin{array}{l}-0.046^{* * *} \\
(19.55)\end{array}$ & $\begin{array}{c}-0.047^{* *} \\
(19.41)\end{array}$ & $\begin{array}{l}-0.047^{* * *} \\
(19.32)\end{array}$ & $\begin{array}{c}-0.047^{* *} \\
(19.53)\end{array}$ & $\begin{array}{l}-0.045^{*} \\
(18.77)\end{array}$ \\
\hline Respondents' wage & & $\begin{array}{c}0.130^{* * * *} \\
(0.09)\end{array}$ & $\begin{array}{c}0.127^{* * * *} \\
(0.09)\end{array}$ & $\begin{array}{c}0.125^{* * *} \\
(0.10)\end{array}$ & $\begin{array}{c}0.111^{* * * *} \\
(0.11)\end{array}$ \\
\hline Work council & & & $\begin{array}{l}0.115^{* * * *} \\
(656.35)\end{array}$ & $\begin{array}{l}0.113^{* * *} \\
(676.50)\end{array}$ & $\begin{array}{l}0.104^{* * *} \\
(696.08)\end{array}$ \\
\hline Availability of workers & & & & $\begin{array}{c}0.009 \\
(167.22)\end{array}$ & $\begin{array}{c}0.002 \\
(189.28)\end{array}$ \\
\hline Retention strategy (Ref.: Always) & & & & $\begin{array}{c}0.000 \\
(.)\end{array}$ & $\begin{array}{c}0.000 \\
(.)\end{array}$ \\
\hline Sometimes & & & & $\begin{array}{l}-0.049^{* *} \\
(426.96)\end{array}$ & $\begin{array}{c}-0.004 \\
(480.33)\end{array}$ \\
\hline Only in exceptional cases & & & & $\begin{array}{c}-0.023 \\
(559.90)\end{array}$ & $\begin{array}{c}0.029 \\
(695.25)\end{array}$ \\
\hline Product market competition & & & & $\begin{array}{c}0.011 \\
(419.29)\end{array}$ & $\begin{array}{c}0.017 \\
(481.88)\end{array}$ \\
\hline Retention rate & & & & & $\begin{array}{c}0.066^{* * *} \\
(542.86)\end{array}$ \\
\hline Still in firm after three years & & & & & $\begin{array}{c}0.056^{* *} \\
(5.75)\end{array}$ \\
\hline Constant & $(12729.62)$ & $(12640.11)$ & $(12586.38)$ & $(12716.92)$ & $(15476.25)$ \\
\hline $\begin{array}{l}\text { Observations } \\
R^{2}\end{array}$ & $\begin{array}{l}2449 \\
0.222\end{array}$ & $\begin{array}{l}2449 \\
0.233\end{array}$ & $\begin{array}{l}2449 \\
0.240\end{array}$ & $\begin{array}{l}2366 \\
0.247\end{array}$ & $\begin{array}{l}1884 \\
0.303\end{array}$ \\
\hline
\end{tabular}

Note: Standardized beta coefficients are displayed; standard errors in parentheses; $* p<0.10, * * p<0.05$, *** $p<0.01$; Controls for economic branch (19), firm size (4), Bundesland (16), occupation (211) included in all models. 


\subsection{Robustness checks}

As a robustness check, I test whether the relation between economic preferences and the training investments is more pronounced for firms that are more investment oriented. This should be the case as a production-oriented firm would benefit from training anyway, irrespective of whether they obtain an additional utility from being altruistic. I differentiate the firms into three groups - those that are production oriented, those firms that are investment oriented, and those firms that follow a mixed strategy. The allocation into investment or production oriented is conducted according to a question which asks firms whether or not they plan to retain their apprentices after the training period. They can either answer "never", "sometimes", or "always". Firms that always (never) retain their apprentices are categorized as investment (production) oriented. Firms that answer that they sometimes retain their apprentices follow a mix of the two strategies.

Differentiating for the training motive reduces the observation for each regression. As a result, the inclusion of occupation dummies is no longer possible. Instead, I include variables that refer to different occupational characteristics as type of occupation ${ }^{21}$, training sector, and length of training program.

The results show that time preferences are only significant when firms are clearly investment oriented. When firms are either mixed or production oriented, the variable is no longer significant. This is expected as firms that are production oriented do not plan to retain their apprentices anyway and thus do not need to rely on the future benefits. The strength with which they weigh the future benefits should hence not influence their decision. A similar picture can be seen with regard to altruism. Here, both investment-oriented firms and those which follow a mixed strategy are influenced by their degree of altruism. For production-oriented firms, the relation is basically zero.

21. The categories are commercial, clerical, and industrial. 
Table 3: Annual investments in apprenticeship training per apprentice in Euro differentiated for training motive

\begin{tabular}{lcccc}
\hline & $\begin{array}{c}(1) \\
\text { Baseline }\end{array}$ & $\begin{array}{c}(2) \\
\text { Investment } \\
\text { oriented }\end{array}$ & $\begin{array}{c}(3) \\
\text { Mix }\end{array}$ & $\begin{array}{c}(4) \\
\text { Production } \\
\text { oriented }\end{array}$ \\
\hline Altruism & $0.045^{* *}$ & $0.056^{* *}$ & $0.096^{* * * *}$ & -0.009 \\
& $(0.65)$ & $(0.86)$ & $(1.12)$ & $(2.43)$ \\
Preference towards the present & $-0.052^{* *}$ & $-0.103^{* * *}$ & -0.053 & 0.055 \\
& $(71.64)$ & $(101.12)$ & $(120.86)$ & $(219.96)$ \\
Number of apprentices & $-0.049^{* *}$ & $-0.057^{* *}$ & -0.050 & $-0.148^{* *}$ \\
& $(19.89)$ & $(19.77)$ & $(97.13)$ & $(257.43)$ \\
Respondents' wage & $0.136^{* * *}$ & $0.106^{* * *}$ & $0.168^{* * *}$ & $0.192^{* * *}$ \\
& $(0.09)$ & $(0.14)$ & $(0.18)$ & $(0.24)$ \\
Works council & $0.131^{* * *}$ & $0.177^{* * *}$ & $0.185^{* * *}$ & -0.002 \\
& $(652.79)$ & $(799.79)$ & $(1361.54)$ & $(2429.71)$ \\
Availability of workers & -0.011 & 0.041 & $-0.124^{* * *}$ & 0.015 \\
& $(155.47)$ & $(215.35)$ & $(271.90)$ & $(522.09)$ \\
Product market competition & 0.020 & 0.045 & -0.037 & 0.056 \\
& $(393.94)$ & $(583.19)$ & $(619.24)$ & $(1237.77)$ \\
Constant & $*$ & & & $*$ \\
& $(2112.82)$ & $(4249.90)$ & $(3516.95)$ & $(5836.15)$ \\
\hline Observations & 2375 & 1342 & 700 & 324 \\
$R^{2}$ & 0.100 & 0.141 & 0.216 & 0.267 \\
\hline Note: Standardized beta coefficients are displayed; standard errors in parentheses; * p $<0.10, * * \mathrm{p}<0.05, * * * \mathrm{p}$
\end{tabular}

\section{Conclusions}

The aim of the paper is to illustrate the relationship between two important economic preferences of decision makers, i.e. altruism and time preferences, and the training behavior of the firms they have to manage. To rule out a potential selection of decision makers to more investment oriented firms, I control for a number of firm specific variables that capture the potential for long-term benefits.

I showed that altruistic decision makers are more likely to provide training places than non-altruistic decision makers. Moreover, altruism is related to the amount of investment in apprenticeship training. This suggests that training decisions in firms are not exclusively motivated by the firms' own material self-interest. Instead, decision makers who are more altruistic seem to take into account the positive effects of offering training places on society and individuals. A positive side effect of altruism is the effect on training quality. In firms with more altruistic decision makers, apprentices are supervised by trainers for more hours. 
Moreover, I showed that time preferences are very strongly associated to the firm's training investments. Decision makers that have a stronger preference for the future are more willing to accept higher training costs because they are aware of the long-term benefits of training.

The paper has two important contributions. Firstly, it goes beyond the cost benefit literature by introducing altruism and time preferences as additional determinants of firms' training decisions and investments. Even though it has been often mentioned by the firms themselves that training apprentices is also seen as service they provide to the apprentices and the society as such, the actual relation of social considerations and the firms' training behavior has never been empirically analyzed.

Secondly, it adds to the behavioral economics literature by presenting empirical evidence on the impact of preferences of vital decision makers within firms on firms' training investments. This suggests that economic preferences are not only relevant in private consumer and labor market choices but can also influence the decision of firms. In this paper, I have shown that two relevant economic preferences have a substantial impact on such an important decision as investing in the dual apprenticeship system in Germany.

The results suggest that appeals to social responsibility and the awareness of the future need for skilled workers can have an effect on firm decisions to invest in training. The requirement for those sorts of campaigns to work is that firms care about the utility or wellbeing of others. If firms did not take into account the benefits of others at all, all campaigns raising the awareness of the social benefits of training would be in vain. The results suggest, however, that more altruistic decision makers are also more likely to invest in training, which means that their decisions are indeed influenced by social considerations. Thus, the requirement for policies that are targeted at increasing the awareness of social benefits of training can be effective is given. Moreover, policy campaigns that address the future need for skilled workers, which have been and are currently used to increase firms' provision in apprenticeship training, are especially relevant for firms with otherwise rather shortsighted decision makers.

Nonetheless, it has to be taken into account that the impact of preferences is much stronger on the actual training investments than on the decision to provide apprenticeship places at all. This result is intuitive as starting to train apprentices requires even higher upfront investments, when the firm did not train before at all. Trainers with a training license have to be employed, machines, tools, and learning materials have to be purchased, internal training strategies and organizations have to be developed, etc. Once the training infrastructure is set up, the decision to accept slightly higher training costs is relatively "easy". Thus, the amount of training investments is more sensitive to variations in the economic preferences of the decision makers than in the probability to be a training firm or not. Moreover, the actual training costs are not only set exogenously. Instead, in practice 
decision makers may have some scope to influence the training costs, for example by providing apprentices with more trainer hours than usual. Thus, more altruistic decision makers or decision makers with a higher preference towards the present could also actively decide to increase the training costs if they know that this will also increase the training quality. This additional influence of economic preferences on the training investments can further explain the stronger and more pronounced coefficients in the investment regressions in contrast to the training probability regression.

For the policy implication, this means that appeals towards social responsibility and future orientation are more likely to be effective with regard to the actual training investments than with regard to the training decisions. In the same way, appeals and campaigns could potentially have a positive impact on training quality. However, while the variation in time preferences is strongly associated with the training investment, it is not associated with the training decision. Moreover, even though the variation in altruism of decision makers is significantly associated to the training probability, the small size of this coefficient suggests that other arguments, such as purely monetary cost benefit considerations, are additionally necessary to convince firms to start to train when they have not done that so far. 


\section{References}

Acemoglu, Daron, and Jorn-Steffen Pischke. 1998. "Why Do Firms Train? Theory and Evidence." The Quarterly Journal of Economics 113(1): 79-119.

Andreoni, James. 1989. "Giving with Impure Altruism: Applications to Charity and Ricardian Equivalence.” Journal of Political Economy: 1447-58.

Armstrong, Mark, and Steffen Huck. 2010. "Behavioral Economics as Applied to Firms: A Primer." Competition Policy International 1: 2-45.

Becker, Gary S. 1962. "Investment in Human Capital: A Theoretical Analysis." The Journal of Political Economy 70(5): 9-49.

—. 1974. “A Theory of Social Interactions.” Journal of Political Economy 82(6): 106393.

Beicht, Ursula, Günter Walden, and Hermann Herget. 2004. "Kosten Und Nutzen Der Betriebliche Berufsausbildung in Deutschland." Berichte zur beruflichen Bildung.

Benhabib, Jess, Alberto Bisin, and Andrew Schotter. 2010. "Present-Bias, Quasi-Hyperbolic Discounting, and Fixed Costs." Games and Economic Behavior 69(2): 205-23. http://dx.doi.org/10.1016/j.geb.2009.11.003.

Bhaskar, V, Alan Manning, and Ted To. 2002. "Oligopsony and Monopsonistic Competition in Labor Markets.” Journal of Economic Perspectives 16(2): 155-74.

Borjas, George J. 2008. Labor Economics. Fourth Edi. New York: McGraw-Hill/Irwin.

Busemeyer, Marius R. 2009. Wandel Trotz Reformstau: Die Politik Der Beruflichen Bildung Seit 1970. Frankfurt, Main: Campus Verlag.

Camerer, Colin, George Loewenstein, and Matthew Rabin. 2004. "Behavioral Economics: Past, Present, Future.” In Advances in Behavioral Economics, New York, 2-51.

Carpenter, Jeffrey, and Caitlin Knowles Myers. 2010. "Why Volunteer? Evidence on the Role of Altruism, Reputation, and Incentives." Journal of Public Economics.

Certo, Trevis S., Brian L. Connelly, and Laszlo Tihanyi. 2008. "Managers and Their Not-so Rational Decisions." Business Horizons 51(2): 113-19.

DellaVigna, Stefano. 2009. "Psychology and Economics: Evidence from the Field." Journal of Economic Literature 47(2): 315-72.

Falk, Armin et al. 2013. “An Experimentally Validated Preference Module.” Working Paper University of Bonn.

Falk, Armin, Benjamin Enke, Anke Becker, and David Huffman. 2015. "The Nature and Predictive Power of Preferences: Global Evidence.”

Fehr, Ernst, and Klaus M Schmidt. 2006. "The Economics of Fairness, Reciprocity, and Altruism - Experimental Evidence and New Theories." In Handbook of the Economics of Giving, Altruism and Reciprocity, Handbook of the Economics of Giving, Altruism and Reciprocity, eds. Serge-Christophe Kolm and Jean Mercier Ythier. Elsevier.

Foraus. 2015. “Attraktivität Der Dualen Berufs- Ausbildung in Verbindung Mit Der Funktion 
Betrieblichen Ausbildungspersonals - Eine Qualitative Empirische Studie.” Arbeitsmaterialien aus dem Arbeitsbereich 3.2.

Fouarge, Didier, Trudie Schils, and Andries De Grip. 2013. "Why Do Low-Educated Workers Invest Less in Further Training?" Applied Economics 45(18): 2587-2601.

Kriechel, Ben, Samuel Mühlemann, Harald Pfeifer, and Miriam Schütte. 2014. "Works Councils, Collective Bargaining, and Apprenticeship Training - Evidence From German Firms.” Industrial Relations 53(2): 199-222.

Leuven, Edwin. 2005. "The Economics of Private Sector Training: A Survey of the Literature." Journal of Economic Surveys 19(1): 91-111.

Lindley, R M. 1975. "The Demand for Apprentice Recruits by the Engineering Industry, 1951-71." Scottish Journal of Political Economy 1: 1-24.

Maier, Tobias, and Günter Walden. 2014. "The Influence of Demographic Factors on the Supply of Company Training Places in Germany." Empirical Research in Vocational Education and Training 6(4).

Matthes, Stephanie, Joachim-Gerd Ulrich, Simone Flemming, and Ralf-Olaf Granath. 2015. "Ausbildungsmarktbilanz." In Datenreport Zum Berufsbildungsbericht 2015, Bonn: Bundesinstitut für Berufsbildung, 10-28.

Merrilees, William J. 1983. "Alternative Models of Apprentice Recruitment: With Special Reference to the British Engineering Industry." Applied Economics 15(1): 1-21.

Mohrenweiser, Jens, and Uschi Backes-Gellner. 2010. “Apprenticeship Training: For Investment or Substitution?" International Journal of Manpower 31(5): 545-62. motive (April 3, 2014).

Mühlemann, Samuel et al. 2010. "The Financing of Apprenticeship Training in the Light of Labor Market Regulations.” Labour Economics 17(5): 799-809.

Schönfeld, Gudrun et al. 2010. Berichte zur beruflichen Bildung Kosten Und Nutzen Der Dualen Ausbildung Aus Sicht Der Betriebe. Ergebnisse Der Vierten BIBB-KostenNutzen-Erhebung. ed. Bundesinstitut für Berufsbildung. Bielefeld.

Smits, Wendy. 2006. "The Quality of Apprenticeship Training.” Education Economics 14(3): 329-44.

Smits, Wendy, and Thomas Zwick. 2004. "Why Do Business Service Firms Employ Fewer Apprentices?: A Comparison between Germany and The Netherlands." International Journal of Manpower 25(1): 36-54.

Statistisches Bundesamt. 2014. 49 Bildungsstand Der Bevölkerung. Wiesbaden.

Stevens, Margaret. 1994. "An Investment Model for the Supply of Training by Employers." Economic Journal 104(424): 556-70.

Uhly, Alexandra. 2015. "Alter Der Auszubildenden Und Ausbildungsbeteiligung Der Jugendlichen Im Dualen System." In Datenreport Zum Berufsbildungsbericht, Bonn: Bundesinstitut für Berufsbildung, 163-71.

Ulrich, Joachim Gerd. 2004. "Wer Ist Schuld an Der Ausbildungsmisere? Diskussion Der Lehrstellenprobleme Aus Attributionstheoretischer Sicht." Berufsbildung in Wissenschaft 
und Praxis 3: 15-19.

Vischer, Thomas. 2012. "Measuring Time Preferences in Representative Samples by Combining Experimental Elicitation and Survey Measures." In Individual Preferences, Human Capital, and Economic Development, , 43-68.

. 2013. "Validating an Ultra-Short Survey Measure of Patience." Economics Letters 120(2): 142-45.

Walden, Günter. 2007. "Short-Term and Long-Term Benefits as Determinants of the Training Behaviour of Companies.” Journal for Labour Market Research 40(2): 3.

Wolter, Stefan C, and Paul Ryan. 2011. "Apprenticeship." In Handbook of the Economics of Education Vol. 3, eds. Eric A. Hanushek, Stephen Machin, and Ludger Woessmann. The Netherlands: North-Holland, 521-76. 


\section{Appendix}

\section{A. Tables}

Table A1: Information about interview partner

\begin{tabular}{l|cccc}
\hline & \multicolumn{4}{|c}{ Decision Making } \\
\hline Position & Alone & With others & $\begin{array}{c}\text { No involvement } \\
\text { in decision }\end{array}$ & Total \\
\hline \hline Non-training firm & 437 & 346 & 73 & 856 \\
Training firm & $51.05 \%$ & $40.42 \%$ & $8.53 \%$ & $100 \%$ \\
& 1,158 & 1,460 & 183 & 2,801 \\
Total & $41.34 \%$ & $52.12 \%$ & $6.53 \%$ & $100 \%$ \\
& 1,595 & 1,806 & 256 & 3,657 \\
\hline \hline
\end{tabular}

Note: Numbers refer to the sample and are not weighted.

Table A2: Descriptive statistics of main variables of interest

\begin{tabular}{l|ccccc}
\hline & $\mathrm{N}$ & Mean & Std. Dev. & Minimum & Maximum \\
& & & & & \\
\hline \hline Training investments & 3032 & $5.657 €$ & $8.648 €$ & $-31.490 €$ & $58.466 €$ \\
Altruism & 3210 & 184,84 & 246,80 & 0 & 1000 \\
Preference towards the present & 3348 & 2,85 & 2,61 & 0 & 10 \\
\hline
\end{tabular}


Table A3: Dep. Var.: Training investments and total trainer hours

\begin{tabular}{|c|c|c|c|}
\hline & $\begin{array}{c}(1) \\
\text { Net costs }\end{array}$ & $\begin{array}{c}(2) \\
\text { Trainer hours }\end{array}$ & $\begin{array}{c}(3) \\
\text { Net costs }\end{array}$ \\
\hline Altruism & $\begin{array}{l}0.050^{* *} \\
(0.75)\end{array}$ & $\begin{array}{c}0.106^{\text {*3*3: }} \\
(0.00)\end{array}$ & $\begin{array}{l}-0.000 \\
(0.66)\end{array}$ \\
\hline Preference towards the present & $\begin{array}{c}-0.085^{* * * *} \\
(85.55)\end{array}$ & $\begin{array}{l}-0.021 \\
(0.15)\end{array}$ & $\begin{array}{c}-0.075^{* * *} \\
(75.42)\end{array}$ \\
\hline Number of apprentices & $\begin{array}{l}-0.045^{*} \\
(18.77)\end{array}$ & $\begin{array}{c}-0.057^{\text {*** }} \\
(0.03)\end{array}$ & $\begin{array}{l}-0.017 \\
(16.58)\end{array}$ \\
\hline Respondents' wage & $\begin{array}{c}0.111^{\text {**** }} \\
(0.11)\end{array}$ & $\begin{array}{c}-0.063^{* * *} \\
(0.00)\end{array}$ & $\begin{array}{c}0.141^{* * *} \\
(0.09)\end{array}$ \\
\hline Works council & $\begin{array}{l}0.104^{* * *} \\
(696.08)\end{array}$ & $\begin{array}{l}-0.004 \\
(1.19)\end{array}$ & $\begin{array}{l}0.106^{* * *} \\
(613.55)\end{array}$ \\
\hline Availability of workers & $\begin{array}{c}0.002 \\
(189.28)\end{array}$ & $\begin{array}{c}-0.066^{* * *} \\
(0.32)\end{array}$ & $\begin{array}{c}0.034 \\
(167.15)\end{array}$ \\
\hline Retention strategy (Ref.: always) & $\begin{array}{c}0.000 \\
(.)\end{array}$ & $\begin{array}{c}0.000 \\
(.)\end{array}$ & $\begin{array}{c}0.000 \\
(.)\end{array}$ \\
\hline Sometimes & $\begin{array}{c}-0.004 \\
(480.33)\end{array}$ & $\begin{array}{l}-0.014 \\
(0.82)\end{array}$ & $\begin{array}{c}0.003 \\
(423.41)\end{array}$ \\
\hline Only in exceptional cases & $\begin{array}{c}0.029 \\
(695.25)\end{array}$ & $\begin{array}{c}-0.061^{* * *} \\
(1.19)\end{array}$ & $\begin{array}{l}0.058^{* *} \\
(613.54)\end{array}$ \\
\hline Product market competition & $\begin{array}{c}0.017 \\
(481.88)\end{array}$ & $\begin{array}{l}-0.036 \\
(0.82)\end{array}$ & $\begin{array}{c}0.034 \\
(424.99)\end{array}$ \\
\hline Retention rate & $\begin{array}{c}0.066^{* *} \\
(542.86)\end{array}$ & $\begin{array}{c}0.095^{* * * *} \\
(0.93)\end{array}$ & $\begin{array}{c}0.021 \\
(480.28)\end{array}$ \\
\hline Still in firm after three years & $\begin{array}{c}0.056^{* *} \\
(5.75)\end{array}$ & $\begin{array}{l}0.050^{*} \\
(0.01)\end{array}$ & $\begin{array}{l}0.032 \\
(5.08)\end{array}$ \\
\hline Trainer hours & & & $\begin{array}{l}0.474^{* * * *} \\
(12.69)\end{array}$ \\
\hline Constant & $(15476.25)$ & $\begin{array}{c}* \\
(26.45)\end{array}$ & (13655.16) \\
\hline $\begin{array}{l}\text { Observations } \\
R^{2}\end{array}$ & $\begin{array}{l}1884 \\
0.303 \\
\end{array}$ & $\begin{array}{l}1884 \\
0.306\end{array}$ & $\begin{array}{l}1884 \\
0.459 \\
\end{array}$ \\
\hline
\end{tabular}




\section{A. Figures}

Figure A1: Distribution of altruism - hypothetical donation

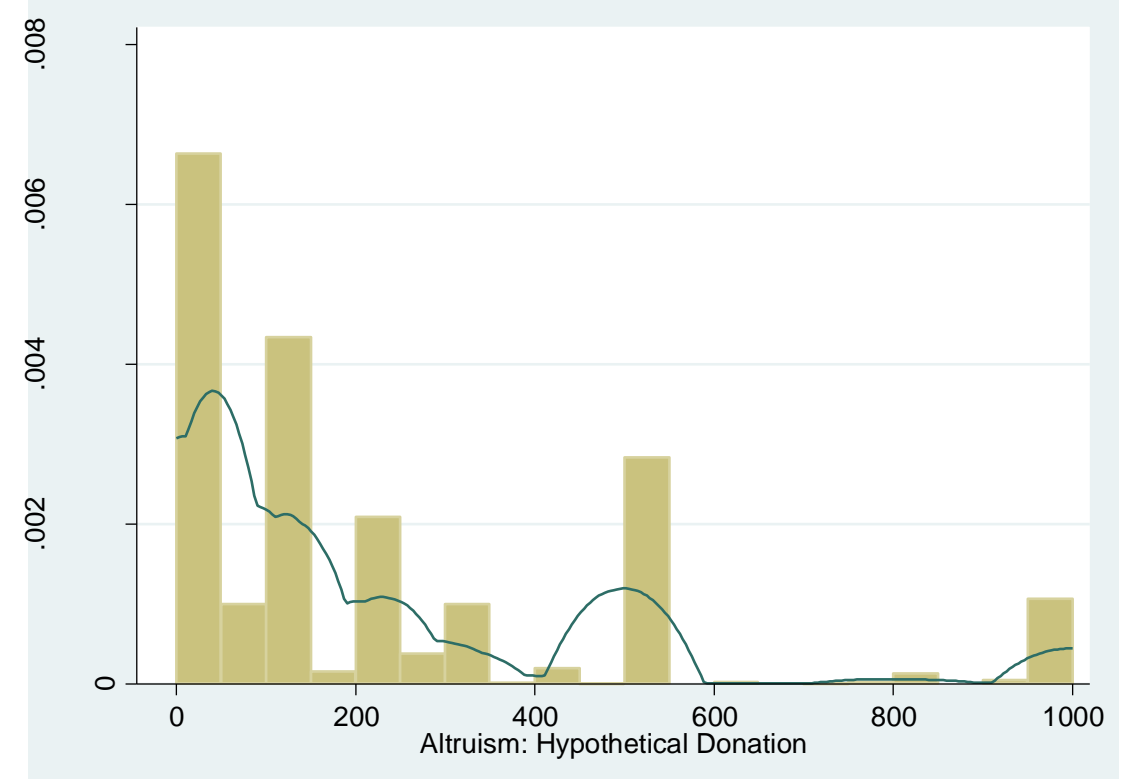

Figure A2: Distribution of time preference - tendency to postpone

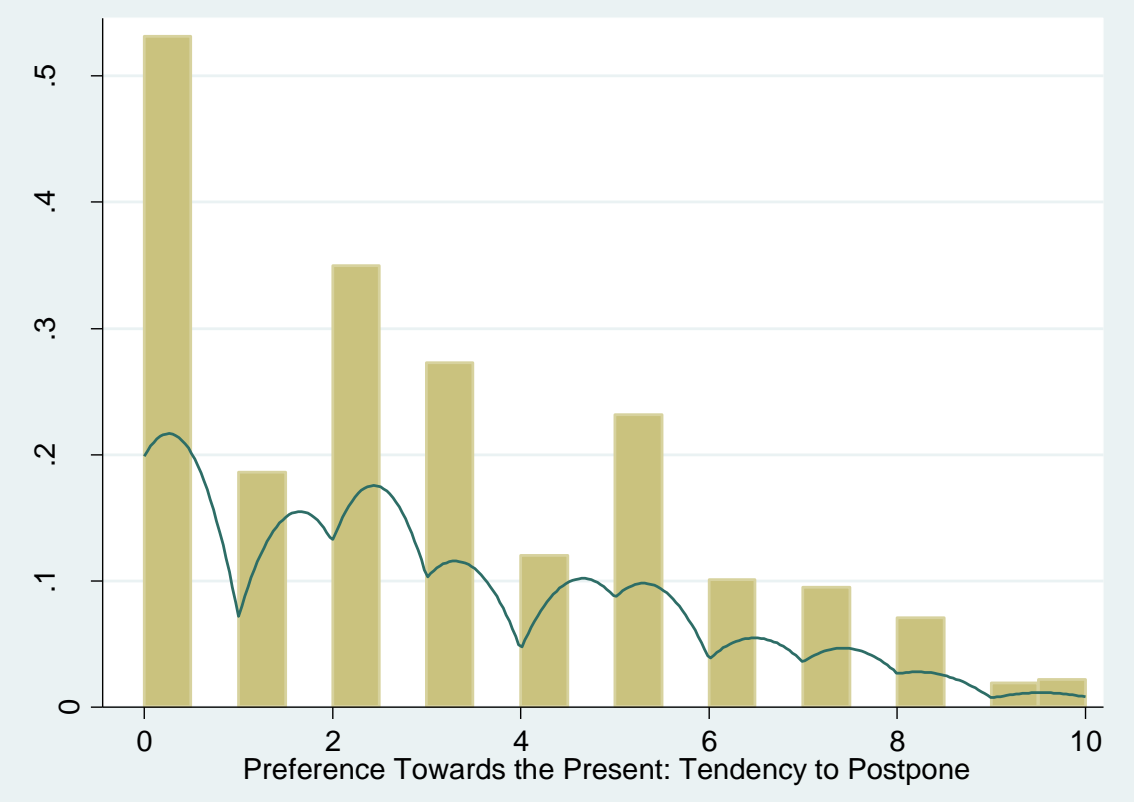


Figure A3: Distribution of training investments (measured by net costs)

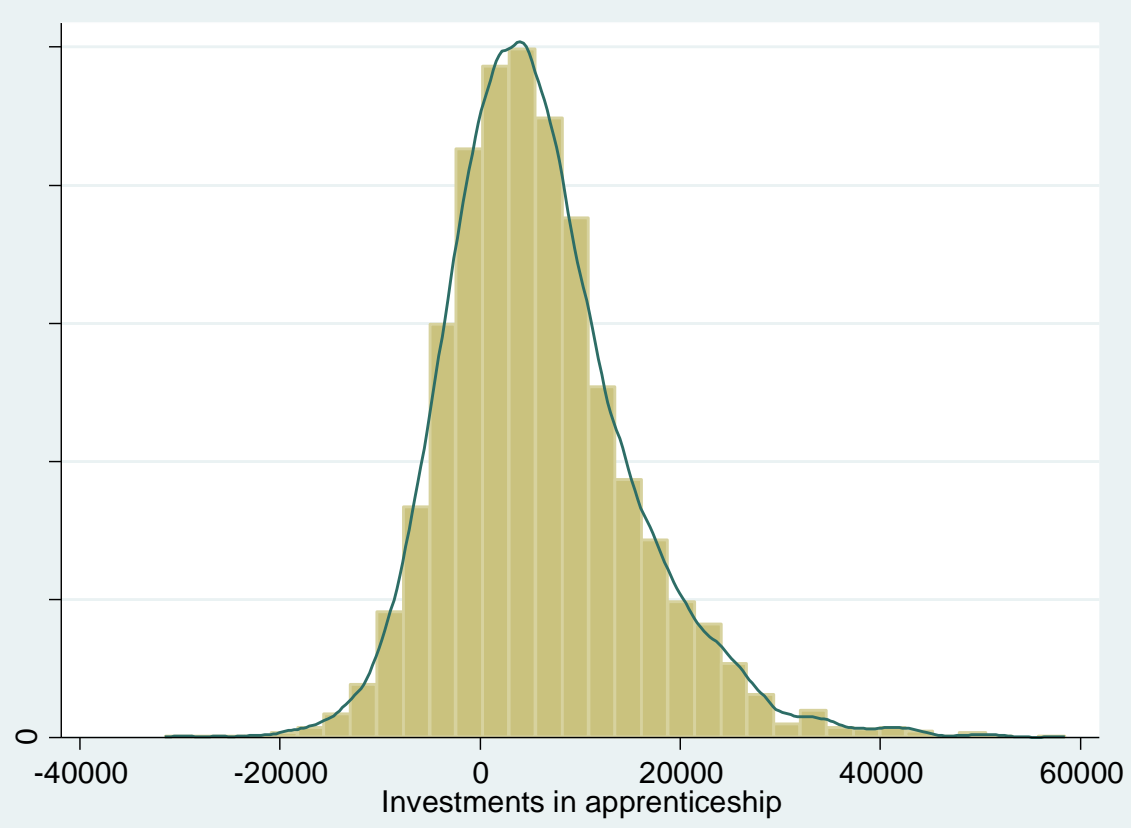

